\title{
PERAN KOPERASI \\ DALAM MEWUJUDKAN PEMBANGUNAN EKONOMI KERAKYATAN
}

\author{
Eef Saefulloh, Wasman, dan Desy Ina Nur Asih \\ Fakultas Syari'ah dan Ekonomi Islam \\ Institut Agama Islam Negeri Syekh Nurjati Cirebon \\ e-mail:eefsae2003@gmail.com,wasman1959@yahoo.co.id, \\ dan desy.nurina30@gmail.com
}

\begin{abstract}
Cooperative as a manifestation of the economic development of democracy. This happens when the cooperative is well managed, The existence of cooperatives in the District of Gunungjati has not described the cooperative as a form of economic development populist.This study aims to answer from the questions that become the formulation of the problem, how SWOT Cooperative as a Form of Community Economic Development in the District of Gunungjati? This research uses qualitative research,The data collected by interview technique (interview), observation, documentation and then analyzed by descriptive method of analysis.The SWOT analysis results that can be submitted by the authors are the cooperatives in the District of Gunungjati has the power in management,And has a weakness of the level of public confidence,Besides the cooperative opportunities for cooperation with financial institutions are very open, On the other hand the threat is the ease of provision of borrowers of informants (middlemen) who are still very difficult to overcome.
\end{abstract}

Keywords: Cooperative, SWOT Analysis, and Community Economic.

\begin{abstract}
Abstrak
Koperasi sebagai wujud dari pembangunan ekonomi kerakyatan. Hal ini terjadi apabila koperasi dikelola dengan baik, keberadaan koperasi di Kecamatan Gunungjati belum mendiskripsikan koperasi sebagai wujud pembangunan ekonomi kerakyatan. Penelitian ini bertujuan untuk menjawab dari pertanyaan-pertanyaan yang menjadi rumusan masalah, bagaimana SWOT Koperasi Sebagai Wujud Pembangunan Ekonomi Kerakyatan di Wilayah Kecamatan Gunungjati? Penelitian ini menggunakan penelitian kualitatif, data yang dikumpulkan dengan teknik interview (wawancara), observasi, dokumentasi kemudian dianalisis dengan metode deskriptif analisis. Adapun hasil analisis SWOT yang dapat disimpulkan oleh penulis adalah koperasi-koperasi di Kecamatan Gunungjati memiliki kekuatan di manajemen, dan mempunyai kelemahan dari tingkat kepercayaan masyarakat, selain itu peluang koperasi untuk kerjasama dengan lembaga keuangan sangat terbuka, disisi lain ancamannya adalah kemudahan penyediaan pinjam informan (tengkulak) yang masih sangat sulit diatasi.
\end{abstract}

Kata Kunci: Koprasi, Analisis SWOT, dan Ekonomi Kerakyatan. 


\section{PENDAHULUAN}

Koperasi berasal dari kata cooperation (bahasa Inggris), yang berarti kerja sama. Sedangkan menurut istilah, yang dimaksud dengan koperasi adalah suatu perkumpulan yang dibentuk oleh para anggotanya dengan harga yang relatif rendah dan bertujuan memajukan tingkat hidup bersama. ${ }^{1}$ Dalam perkembangannya koperasi menjadi salah satu sistem sendiri dalam kehidupan ekonomi masyarakat sebagai upaya untuk memenuhi kebutuhan hidup dan memecahkan persoalan ekonomi, persoalan ekonomi yang utama dihadapi oleh masyarakat tidak lepas dari bagaimana memenuhi kebutuhan hidupnya yang tidak terbatas, sedangkan sumber-sumber ekonomi sangat terbatas. Koperasi di Indonesia dewasa ini bila dilihat dari segi kuantitas memang sangat menggembirakan, akan tetapi bila dilihat dari segi kualitas masih sangat memprihatinkan, karena kemampuan dan kualitas koperasi yang ada sekarang masih belum mencapai sebagaimana yang diharapkan.

Bagi mereka yang tidak mendukung dan berperan serta dalam pelaksanaan pembangunan koperasi di Indonesia, sama saja tidak mendukung pelaksanaan UndangUndang Dasar 1945, khususnya pasal 33 ayat I bahwa: "perekonomian Indonesia disusun secara usaha bersama dan berdasarkan atas azas kekeluargaan". ${ }^{2}$ Saat ini di Indonesia terdapat 209 ribu koperasi yang tersebar diseluruh wilayah. Tetapi sangat disayangkan dari jumlah tersebut, sekitar 70 persen sudah tidak aktif lagi, hanya 30 persen koperasi di Indonesia yang masih aktif. Hal ini mengindikasikan kondisi koperasi di Indonesia saat ini masih memprihatinkan angka koperasi yang tidak aktif memang cukup tinggi. Salah satunya masyarakat di Kecamatan Gunungjati

\footnotetext{
${ }^{1}$ Hendi Suhendi, Fiqh Muamalah (Jakarta: Rajawali Pers, 2013), 289.

${ }^{2}$ Pandji Anoraga dan Ninik Widiyanti, Dinamika Koperasi (Jakarta: PT. Rineka Cipta, 2007), 142-143.
}

berdasarkan data dari Kecamatan Gunungjati, menjelaskan kondisi koperasi yang ada di Kecamatan Gunungjati saat ini sangat memprihatinkan, karena hasil rekapitulasi koperasi di Kabupaten Cirebon tahun $2015,{ }^{3}$ khususnya wilayah Kecamatan Gunungjati jumlah koperasi ada 32 koperasi yang aktif berjumlah 25 dan yang pasif berjumlah 7 sedangkan yang melaksanakan Rapat Anggaran Tahunan (RAT) berjumlah 8 koperasi dan rencana di tahun 2017, nama 22 koperasi di Kecamatan Gunungjati akan diusulkan oleh Dinas Koperasi dan Usaha Mikro Kecil Menengah di Kabupaten Cirebon untuk dibubarkan atau dilidasi.

Dengan alasan karena banyak koperasi yang didirikan namun status koperasinya yang belum jelas tidak ada laporan perkembangan dari hasil dari pelaksanaan RAT kepada pihak Kecamatan Gunungjati maupun di Dinas Koperasi dan Usaha Mikro Kecil Menengah di Kabupaten Cirebon, banyak koperasi yang didirikan tetapi tidak sesuai dengan Undang-Undang No. 25 Tahun 1992 tentang Perkoperasian, melainkan dengan tujuan untuk kepentingan pribadi ataupun memperkaya dirinya sendiri bahkan ada perusahaan bodong yang bertopeng atas nama koperasi, dan juga banyak koperasi yang sudah mati atau tidak berjalan sama sekali atau jalan di tempat dikarenakan tidak ada pengurus dan anggota sehingga yang ada hanya papan namanya saja, selain itu juga ada koperasi tetapi status koperasinya lagi sakit dikarenakan pemberdayaan sumber daya anggotanya sangat kurang, manajemen pembiayaan, dan manajemen dalam permodalannya masih sangat kurang.

Oleh karena itu, penulis merasa perlu untuk mengkaji lebih dalam lagi mengenai 1) Bagaimana kekuatan koperasi sebagai wujud pembangunan ekonomi kerakyatan di wilayah Kecamatan Gunungjati; 2) Bagaimanakelemahan

${ }^{3}$ Udin Handayani, "Rekapitulasi Koperasi di Kabupaten Cirebon Tahun 2015”, Makalah (Cirebon: Koperasi dan Usaha Mikro Kecil Menengah, 2017). 
koperasi sebagai wujud pembangunan ekonomi kerakyatan di wilayah Kecamatan Gunungjati? 3) Bagaimana peluang perkembangan koperasi sebagai pelaku ekonomi kerakyatan di wilayah Kecamatan Gunungjati? 4) Bagaimana ancaman perkembangan koperasi sebagai pelaku ekonomi kerakyatan di wilayah Kecamatan Gunungjati? 5) Bagaimana solusinya terhadap koperasi sebagai pelaku ekonomi kerakyatan di wilayah Kecamatan Gunungjati?

\section{LITERATURE REVIEW}

Penelitian tentang analisis swot koperasi dalam pembangunanan ekonomi kerakyatan bukanlah suatu yang baru. Meskipun demikian, nampaknya belum ditemukan penelitian yang secara spesifik. Berikut beberapa karya yang terdokumentasikan terkait permasalahan yang dikaji, yaitu pertama, penelitian yang dilakukan oleh Heriyono dalam "Peran Koperasi dalam Pengembangan Perekonomian Rakyat". Penelitian ini memfokuskan kepada peran koperasi dalam memberdayakan ekonomi rakyat di Kota Medan pada Tahun 2014. Menurutnya, bahwa faktor-faktor yang mendorong masyarakat menggunakan jasa koperasi adalah pelayanan, lokasi, serta keinginan masyarakat untuk menambah pendapatannya. Untuk menjalankan prinsip koperasi. koperasi harus terus meningkatkan kualitas kinerja, pelayanan, permodalan guna membangun citra koperasi sebagai koperasi simpan pinjam yang lebih baik kedepannya.

Kedua, penelitian yang dilakukan oleh Darmadi pada tahun 2013. ${ }^{5}$ Penelitian ini tentang "Peranan KJKS BMT ElGunung Jati terhadap Pemberdayaan

\footnotetext{
${ }^{4}$ Heriyono, "Peran Koperasi dalam Pengembangan Perekonomian Rakyat", Jurnal Ekonomi, Vol. 1, No. 1 (Desember, 2012).

${ }^{5}$ Darmadi,“Peranan KJKS BMT El-Gunung Jati Terhadap Pemberdayaan Ekonomi Masyarakat (Studi kasus pada nasabah KJKS BMT El-Gunung Jati)", Skripsi (Cirebon: Muamalah Ekonomi Perbankan Islam IAIN Syekh Nurjati, 2013), 85.
}

Ekonomi Masyarakat (Studi Kasus pada Nasabah KJKS BMT El-Gunung Jati)". Menurutnya, peranan pembiayaan murabahah yang diberikan oleh KJKS BMT El-Gunung Jati sudah memberikan kontribusi yang cukup signifikan terhadap usaha nasabah sehingga nasabah mampu memenuhi kebutuhan baik kebutuhan primer maupun sekundernya bahkan nasabah mampu membuka usaha dengan dananya sendiri. Adapun peranan pembinaan juga dapat dirasakan oleh nasabah meskipun pembinaan yang dilakukan hanya bersifat perorangan, namun itu sudah dirasa membantu karena dengan adanya pembinaan yang dilakukan oleh BMT yang berupa pendampingan, pengawasan dan motivasi terhadap nasabah , kini perkembangan ekonomi nasabah semakin meningkat, selain itu nasabah kini juga memiliki semangat, percaya diri dan memiliki manajemen yang lebih baik.

Dan ketiga, penelitian yang dilakukan oleh Luthf Novian Dwi Nugroho, ${ }^{6}$ tentang "peranan koperasi simpan pinjam terhadap kesejahteraan anggota (studi kasus di koperasi Ampera Indonesia)" pada tahun 2015. Dalam penelitian ini bahwa pengelolaan dana koperasi diperuntukan untuk membantu usaha mikro dalam meningkatkan kesejahteraan khususnya dalam bidang ekonomi. Kesejahteraan anggota sangat dipengaruhi oleh pendapatan yang dihasilkan dalam melaksanakan tugasnya sebagai wirausahawan. Diakui bahwa pada umumnya tingkat pendapatan masyarakat merupakan salah satu faktor penting yang menentukan tingkat kesejahteraan mereka.

Dari ketiga topik penelitian yang telah dipaparkan di atas, secara umum sangat berkaitan erat dengan penelitian yang akan peneliti lakukan, akan tetapi secara

${ }^{6}$ Luthf Novian Dwi Nugroho, "Peranan Koperasi Simpan Pinjam terhadap Kesejahteraan Anggota (studi kasus di koperasi Ampera Indonesia)", Skripsi (Cirebon: Program Studi Ekonomi Perbankan Islam IAIN Syekh Nurjati, 2015), 78. 
khusus peneliti tersebut sedikit berbeda, karena dalam penilitian ini digunakan analisis SWOT. Di sinilah letak perbedaan studi ini dengan studi-studi yang telah dilakukan sebelumnya.

\section{METODOLOGI PENELITIAN}

Jenis penelitian yang digunakan adalah penelitian deskriptif kualitatif karena peneliti mencoba mendeskripsikan suatu gejala, peristiwa, kejadian yang terjadi saat sekarang. Penelitian deskriptif memusatkan perhatian pada masalah aktual sebagaimana adanya pada saat penelitian berlangsung. ${ }^{7}$ Dengan alasan untuk menggambarkan strategi pengembangan usaha koperasi untuk meningkatkan kemampuan koperasi dalam menciptakan lapangan usaha dan pemanfaatan peluang usaha bagi masyarakat sekitar berdasarkan prinsip koperasi yang berazaskan kekeluargaan, koperasi mewujudkan keadilan sosial bagi seluruh rakyat di wilayah Kecamatan Gunungjatipada bulan Maret s.d Mei 2017 dengan membuat catatan yang ekstensif.

Metode yang digunakan dalam penelitian ini adalah metode penelitian kualitatif deskriptif, yaitu data yang dikumpulkannya berupa kata-kata, gambar, dan bukan angka-angka. Data yang didapat dari naskah wawancara, catatan lapangan, foto, videotape, dokumen pribadi, catatan atau memo, dan dokumen resmi lainnya. ${ }^{8}$ Penelitian kualitatif menggunakan metode kualitatif yaitu pengamatan, wawancara, atau penelaahan dokumen.Metode ini menyajikan secara langsung hakikat hubungan antara peneliti dan responden. ${ }^{9}$

Pendekatan penelitian ini adalah pendekatan kualitatif, yaitu secara alamiah

\footnotetext{
${ }^{7}$ Juliansyah Noor, Metodologi Penelitian Skripsi, Tesis, Disertasi dan Karya Ilmiah (Jakarta: Kencana, 2011), 34-35.

${ }^{8}$ Lexy J. Moeleong, Metodologi Penelitian Kualitatif (Bandung: PT. Remaja Rosdakarya, 2013), 11.

${ }^{9}$ Moeleong, Metodologi Penelitian Kualitatif, 10 .
}

(natural setting) mengumpulkan data lapangan. Dalam pendekatan kualitatif tersebut, sumber data yang diperlukan adalah data primer dan data sekunder. Data primer didapatkan melalui secara langsung denganmelakukan wawancara dengan pihak pengelola lembaga koperasi, anggota sebagai pemilik modal, dan aparatur pemerintah Kecamatan Gunungjati. Adapun data sekunder yang digunakan di sini yaitu, membaca literatur kepustakaan, internet, media cetak yang ada hubungannya dengan penelitian yang dilakukan. Data ini digunakan oleh peneliti sebagai data pelengkap dari data primer.

Metode pengumpulan data yang digunakan adalah observasi, wawancara, dan dokumentasi. Pertama, dilihat dari segi proses pengumpulan data, observasi adalah alat pengumpulan data yang dilakukan dengan cara mengamati dan mencatat secara sistematik gejala-gejala yang diselidiki. ${ }^{10}$ Dalam hal ini peneliti menggunakan observasi non-partisipan, yaitu peneliti hanya melihat dan mendengarkan pada situasi sosial tertentu tanpa partisipasi aktif di dalamnya. ${ }^{11}$ Observasi dilakukan untuk mengamati masyarakat secara langsung dalam mengelola dana usaha yang bersumber dari koperasi. Kedua, wawancara adalah peneliti dapat melakukan face-toface interview (wawancara berhadaphadapan) dengan partisipan, mewawancarai mereka dengan telepon, atau terlibat dalam focus group interview (interview dalam kelompok tertentu) yang terdiri dari enam sampai delapan partisipan per kelompok. Wawancara-wawancara seperti itu tentu saja memerlukan pertanyaan-pertanyaan yang secara umum tidak terstruktur dan bersifat terbuka yang dirancang untuk memunculkan

${ }^{10}$ Cholid Narbuko dan Abu Ahmadi, Metodologi Penelitian (Jakarta: Bumi Aksara, 2007), 70 .

${ }^{11}$ Emzir, Metodologi Penelitian Kualitatif:
Analisis Data (Jakarta: Rajawali Press, 2012), 40. 
pandangan dan opini dari para partisipan. ${ }^{12}$ Dalam hal ini, peneliti melakukan proses wawancara mendalam dengan pihak pengurus koperasi untuk mengetahui perkembangan dan pengelolaan koperasi sebagai distribusi modal usaha kepada anggota dan masyarakat sekitarnya, dalam memenuhi kebutuhan usaha yang didirikan koperasi disetiap desa Kecamatan Gunungjati.Serta dampaknya kepada masyarakat terhadap pengelolaan koperasi yang membantu masyarakat sekitar untuk mengembangkan usaha dan memudahkan masyarakat ketika ingin meminjam ataupun menyimpan modal untuk dikelola bersama berdasarkan azas kekeluargaan di koperasi yang ada di wilayah Kecamatan Gunungjati.

Dan Ketiga, dokumentasi adalah mencari data mengenai hal-hal atau variabel yang berupa catatan, transkrip, buku, surat kabar, majalah, prasasti, dan sebagainya. ${ }^{13}$ Dokumentasi merupakan cacatan perisiwa yang sudah berlalu yang berbentuk tulisan, gambar, atau karya monumental dari seseorang studi dokumentasi ini mengambil data koperasi aktif yang berada di Kecamatan Gunungjati untuk dipelajari lebih lanjut. Menurut Sugiyono bahwa dokumentasi merupakan pelengkap dari penggunaan metode observasi danwawancara. Dalam pelaksanaannya teknik ini akan digunakan peneliti intuk mendapatkan data. Hasil penelitian ini akan lebih dapat dipercaya jika didukung oleh dokumentasi yang dilakukan untuk berbagai kegiatan selama penelitian di Kecamatan Gunungjati.

Penelitian ini menggunakan Peneliti menggunakan teknik sampling (penentuan informasi) dengan cara purposive sampling. Purposive sampling adalah teknik pengambilan sampel sumber data dengan pertimbangan tertentu. Pertimbangan

\footnotetext{
${ }^{12}$ John W. Creswell, Research Design Pendekatan Kualitatif, Kuantitatif, dan Mixed (Yogyakarta: Pustaka Pelajar, 2013), 267.

${ }^{13}$ Suharsimi Arikunto, Prosedur Penelitian (Jakarta: PT. Raja Grafindo Persada, 1993), 236.
}

tertentu ini, misalnya orang tersebut yang dianggap paling tahu tentang apa yang peneliti harapkan atau mungkin dia sebagai penguasa sehingga akan memudahkan peneliti menjelajahi objek atau situasi sosial yang diteliti. ${ }^{14}$

\section{KONSEP DASAR}

\section{Koperasi dalam Pembangunan Ekonomi Kerakyatan}

Berdasarkan Undang-Undang No. 25 Tahun 1992 tentang perkoperasian, koperasi adalah badan usaha yang beranggotakan orangorang atau badan hukum koperasi dengan melandaskan kegiatannya berdasarkan prinsip koperasi sekaligus sebagai gerakan ekonomi rakyat yang berdasarkan atas azas kekeluargaan. ${ }^{15}$

Menurut Masjfuk Zuhdi, yang dimaksud dengan koperasi adalah suatu perkumpulan atau organisasi yang beranggotakan orang-orang atau badan hukum yang bekerja sama dengan penuh kesadaran untuk meningkatkan kesejahteraan anggota atas dasar sukarela secara kekeluargaan. ${ }^{16}$ Sebagian ulama menyebutkan Koperasi dengan syyirkah ta'awuniyah (persekutuan tolongmenolong), yaitu suatu perjanjian kerja sama antara dua orang atau lebih, yang satu pihak menyediakan modal usaha, sedangkan pihal lain melakukan usaha atas dasar profit sharing (membagi keuntungan) menurut perjanjian. Dalam Koperasi ini terdapat unsur mudharabah karena suatu pihak memiliki modal dan pihak lain melakukan usaha atas modal tersebut.

Di dalam al-Qur'an surat al-Maidah ayat 2 Allah Swt berfirman:

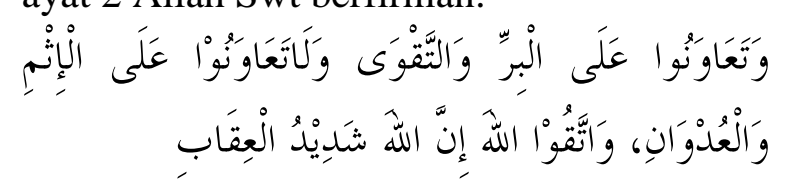

\footnotetext{
${ }^{14}$ Sugiyono, Metode Penelitian Kualitatif dan R\&D (Bandung: C.V. Alfabeta, 2012), 231.

${ }^{15}$ Sonny Sumarsono, Manajemen Koperasi (Teori dan Praktik) (Yogyakarta: Graha Ilmu, 2003), 1.

${ }^{16}$ Hendi Suhendi, Fiqh Muamalah, 289.
} 
Artinya: Dan tolong-menolong kamu dalam (mengerjakan) kebaikan dan takwa, dan jangan tolongmenolong dalam berbuat dosa dan pelangaran. Dan bertakwalah kamu kepada Allah sesungguhnya Allah amat berat siksa-Nya. ${ }^{17}$

Berdasarkan ayat al-Qur'an di atas kiranya dapat dipahami bahwa tolongmenolong dalam kebajikan dan dalam ketakwaan dianjurkan oleh Allah. Koperasi merupakan salah satu bentuk tolongmenolong, kerja sama, dan saling menutupi kebutuhan. menutupi kebutuhan dan tolongmenolong kebajikan adalah salah satu wasilah untuk mencapai ketakwaan yang sempurna (haqa tuqatih). ${ }^{18}$

Di dalam salah satu hadist qudsi yang diriwayatkan oleh Abu Hurairah Radhiyallahu anhu bahwa Rasulullah Swa bersabda: ${ }^{19}$

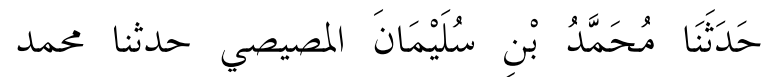
الزبرقان عن أبي حيان التيمي عن أبيه عن أبي هريرة

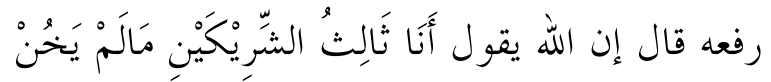

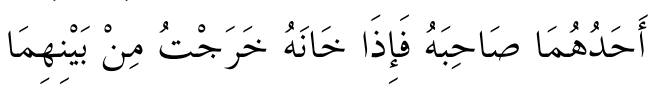

Artinya: Telah menceritakan kepada kami Muhammad bin Sulaiman Al Mishshishi, telah menceritakan kepada kami Muhammad bin Az Zibriqan, dari Abu Hayyan At Taimi, dari ayahnya dari Abu Hurairah dan ia merafa'kannya. Ia berkata; sesungguhnya Allah berfirman: "Aku adalah pihak ketiga dari dua orang yang bersekutu, selama tidak ada salah seorang diantara mereka yang berkhianat kepada sahabatnya.

\footnotetext{
${ }^{17}$ QS Al-Maidah (5): 2.

${ }^{18}$ Hendi Suhendi, Fiqh Muamalah, 295.

${ }^{19}$ Rozalinda, Fikih Ekonomi Syariah (Jakarta: Rajawali Pers, 2016), 192.
}

Apabila ia telah mengkhianatinya,
maka aku keluar dari keduanya.

Tujuan utama pendirian koperasi adalah untuk meningkatkan kesejahteraan ekonomi para anggotanya, namun demikian, karena dalam memperjuangkan peningkatan kesejahteraan ekonomi anggotanya itu koperasi berpegang pada asas dan prinsipprinsip ideal tertentu, maka kegiatan koperasi biasanya juga diharapkan dapat membantu meningkatkan kesejahteraan masyarakat secara keseluruhan dan keberadaan koperasi juga dimaksudkan untuk pembangunan suatu tatanan perekonomian tertentu. Adapun tujuan koperasi adalah memajukan kesejahteraan anggota pada khususnya dan masyarakat pada umumnya serta ikut membangun tatanan perekonomian nasional dalam rangka mewujudkan masyarakat yang maju, adil, dan makmur berlandaskan pancasila dan Undang-Undang Dasar $1945 .^{21}$

Asas koperasi adalah dalam bahasa Inggrisnya disebut Cooperative Principles yang berasal dari bahsa latinPrincipium yang berarti basis atau landasan dan inipun bisa mempunyai beberapa pengertian yaitu sebagai cita-cita utama atau kekuatan/peraturan dari organisasi. Fungsi koperasi dapat diartikan sebagai alat untuk mencapai tujuan yang jelas dan tegas. Koperasi pada hakekatnya hanyalah merupakan alat untuk mencapai tujuan. Dan Nilai-nilai yang menjadi dasar koperasi adalah kemandirian, bertanggungjawab, demokrasi, kesetaraan, keadilan, dan solidaritas. Nilai-nilai etika yang diyakini anggota adalah kejujuran, keterbukaan, tanggungjawab sosial, dan perhatian terhadap sesama.

\footnotetext{
${ }^{20}$ HR. Abu Daud, No. 2936. Lihat Lidwa Pusaka i-Software, Kitab 9 Imam Kutubut Tis'ah, 2009.

2009. ${ }^{21}$ Sonny Sumarsono, Manajemen Koperasi (Teori dan Praktik), 6.
} 


\section{Pembangunan Ekonomi Kerakyatan}

pembangunan adalah pembangunan daerah pedesaan. Pembangunan desa juga harus secara total dan terintegrasi meliputi seluruh bidang kehidupan kemasyarakatan, yaitu ekonomi, sosial, politik dan budaya, ini berarti harus diadakan investasi besarbesaran di daerah pedesaan. Pembangunan desa sebagai keseluruhan dalam bentuk investasi, baik dalam hardware maupun software akan dapat menjamin suatu kebangkitan dari daerah yang selama ini sangat lemah. Kearah kekuatan yang dapat menimbulkan harapan dikemudian hari. ${ }^{22}$

Ekonomi kerakyatan adalah gagasan penting cara, sifat, dan tujuan pembangunan dengan sasaran utama perbaikan nasib rakyat pada umumnya bermukim di pedesaan. Ekonomi kerakyatan mengadakan perubahan penting $\mathrm{k}$ earah kemajuan, khususnya ke arah pendobrakan ikatan serta halangan yang membelenggu bagian terbesar rakyat Indonesia dalam keadaan serba kekurangan dan keterbelakangan. Untuk itu sangat diperlukan perubahan politik. Demokrasi yang murni dan sejati harus menjamin kebebasan serta terbukanya kesempatan untuk ikut serta dalam segala persoalan masyarakat. ${ }^{23} \mathrm{Jadi}$, dengan adanya pembangunan ekonomi kerakyatan adalah perkembangan ekonomi kelompok masyarakat yang mengikut sertakan seluruh lapisan masyarakat dalam proses pembangunan yang berkaitan erat dengan aspek keadilan, demokrasi ekonomi, keberpihakan pada ekonomi rakyat yang bertumpu pada mekanisme pasar yang adil dengan tujuan untuk peningkatan kesejahteraan ekonomi seluruh keseluruhan atau mayoritas masyarakat.

\footnotetext{
${ }^{22}$ Sarbini Sumawinata, Politik Ekonomi Kerakyatan (Jakarta: Gramedia Pustaka Utama, 2004), 132.

${ }^{23}$ Sarbini Sumawinata, Politik Ekonomi Kerakyatan, 161.
}

\section{Peran Koperasi dalm Pembangunan Ekonomi Kerakyatan}

Menurut pasal 3 UU No. 12 Tahun 1967 tentang Pokok-pokok Perkoperasian, disebutkan bahwa koperasi Indonesia adalah organisasi ekonomi rakyat yang berwatak sosial, beranggotakan orang-orang atau badan hukum koperasi yang merupakan tatanan susunan ekonomi sebagai usaha bersama berdasarkan azas kekeluargaan. ${ }^{24}$ Peranan koperasi dalam meningkatkan produksi mewujudkan pendapatan yang adil dan kemakmuran yang merata, keberhasilan koperasi dalam mencapai tujuannya tergantung dari aktivitas para anggotanya, apakah mereka mampu melaksanakan kerja sama, memiliki kegairahan kerja dan mentaati segala ketentuan dan garis kebijakan yang telah ditetapkan Rapat anggota.

Koperasi sebagai gerakan ekonomi partisipan menyatupadukan potensi-potensi kecil yang terpisah-pisah menjadi kekuatan bersama yang lebih besar, menciptkan sinergi.Pada tahap perkembangan tertentu, kemampuan koperasi masih terlalu kecil untuk melaksanakan tugas pemerataan ekonomi yang teramat besar yang ada di luar dirinya. Disebabkan sebagai lembaga yang terbangun atas usaha partisipatif dan semangat kerjasama, maka peranan koperasi berkesesuaian dengan tugas-tugas yang menyangkut stabilitas sosial di pihak lain, ${ }^{25}$ dalam kenyataannya usaha-usaha swasta memang telah membuktikan peranannya dalam mendorong dan menghasilkan ekonomi, mesti dalam periode resesi ia juga paling besar peranannya dalam menurunkan tingkat pertumbuhan ekonomi. Bahkan, terkadang membawa stagnasi dan depresi. Swasta dapat pula mengemban tugas pemerataan dengan memperluas lapangan kerja, melakukan pilihan teknologi yang

\footnotetext{
${ }^{24}$ Pandji Anoraga dan Ninik Widiyanti, Dinamika Koperasi, 163.

${ }^{25}$ Sri Edi Swasono, Koperasi: Nilai-Tambah Ekonomi, Nilai-Tambah Sosial-Kultural, Sokoguru Perekonomian (Jakarta: Yayasan Hatta, 2005), 37.
} 
tepat guna dan dapat karya, memperluas keterkaitan kegiatan usaha dan menumbuhkan sinergi, membayar pajak progresif dan dengan kemampuan pertumbuhannya dapat lebih mampu membiayai proses demokratisasi. ${ }^{26}$

\section{Analisis SWOT Koperasi dalam Pembangunan Ekonomi Kerakyatan}

Menurut Dawam Rahardjo yang dikemukakan oleh Suhendi ${ }^{27}$, koperasi dilahirkan di negara kapitalis. Koperasi dianggap sebagai alternatif atas sistem kapitalis. Koperasi ingin mengganti hubungan produksi dan pertukaran yang berdasarkan pada persaingan bebas dengan kerja sama. Akan tetapi, koperasi tidak menggantikan sistem kapitalis, bahkan koperasi yang baik adalah koperasi yang dapat bekerja dan mampu bersaing dalam kerangka sistem kapitalis. $^{28}$ Dalam perjalanannya setiap perusahaan pastinya dipengaruhi oleh 2 faktor utama yaitu faktor internal dan eksternal. Faktor internal berupa kekuatan dan kelemahan perusahaan tersebut, dan faktor eksternal yang dimaksud adalah peluang dan ancaman yang berasal dari luar perusahaan. Empat hal tersebut merupakan dasar melakukan analisa terhadap keberlangsungan suatu perusahaan kedepannya.

Begitupun dengan koperasi yang ada di Indonesia. Koperasi juga akan dipengaruhi oleh 2 faktor utama dalam mementukan keberlangsungannya di masa mendatang. ${ }^{29}$ Dalam pengembangan koperasi sebagai ekonomi, berdasarkan pada analisis SWOT dengan pendekatan kualitatif sebagaimana dikembangkan oleh Kearns menampilkan delapan kotak, yaitu dua

\footnotetext{
${ }^{26}$ Abdul Bashith, Ekonomi Kemasyarakatan (Bandung: UIN-Maliki Press, 2012),106.

${ }^{27}$ Hendi Suhendi, Fiqh Muamalah, 293-294.

${ }^{28}$ Ismail Nawawi, FikihMuamalah Klasik dan Kontemporer (Bogor: Ghalia Indonesia, 2012), 295.

${ }^{29}$ Euis Amalia, Keadilan Distrubusi Dalam Ekonomi Islam Penguatan Peran LKM dan UKM di Indonesia (Jakarta: Rajawali Pers, 2009), 214.
}

paling atas adalah kotak faktor eksternal (Peluang dan Tantangan) sedangkan dua kotak sebelah kiri adalah faktor internal (Kekuatan dan Kelemahan. Empat kotak lainnya merupakan kotak isu-isu strategis yang timbul sebagai hasil titik pertemuan antara faktor-faktor internal dan eksternal.

\section{PEMBAHASAN DAN DISKUS}

Hasil analisis SWOT dengan memberikan solusi kepada koperasi yang ada di Kecamatan Gunungjati tentang koperasi sebagai wujud pembangunan ekonomi kerakyatan di Kecamatan Gunungjati, setiap organisasi akan menghadapi masalah lingkungan strategis yang mencangkup lingkungan internal dan lingkungan eksternal. Lingkungan internal merupakan faktor yang berpengaruh pada kinerja organisasi yang dapat dikendalikan secara langsung, sedangkan lingkungan eksternal faktor yang berpengaruh pada organisasi tetapi di luar kendali organisasi tersebut.

Sehingga dapat disimpulkan bahwa koperasi yang ada di Kecamatan Gunungjati khususnya dalam pembangunan ekonomi kerakyatan belum terdeskripsikan sepenuhnya untuk dirasakan oleh masyarakat ekonomi menengah karena masih banyak masyarakat yang belum sepenuhnya mempercayai keberadaan koperasi, selain itu juga karena kehadiran para penyediaan pinjaman informan (tengkulak) yang masih sulit diatasi di Kecamatan Gunungjati dengan memberikan pinjaman secara mudah dan cepat tanpa adanya tanggungan.

Sehingga penulispun memberikan solusi untuk koperasi yang ada di Kecamatan Gunungjati agar dengan adanya strategi dengan menggunakan analalisis SWOT koperasi kedepannya lebih maju untuk membangun perekonomian ekonomi kerakyatan di Kecamatan Gunungjati solusi yang diberikan sebagai berikut:

Solusi dari kekuatan dan peluang untuk koperasi yang ada di wilayah Kecamatan Gunungjati agar koperasinya berkembang sebagai wujud dalam 
pembangunan ekonomi kerakayatan adalah koperasi yang kuat atau sehat dalam sistem manajemen yang diterapkan sesuai dengan peraturan Undang-Undang No. 25 Tahun 1992 dan didukung dengan menggunakan sistem aplikasi keuangan yang mempermudah dalam mengerjakan pekerjaan, sumber daya manusianya kuat maka akan mempengaruhi penambahan modal koperasi dengan melakukan kerjasama dengan perbankan maupun dengan koperasi lainnya. Meningkatkan promosi dengan memberikan pembuktian bahwa keberadaan koperasi sangat membantu membangun perekonomian rakyat menengah, sehingga koperasi mendapatkan kepercayaan kembali dari masyarakat sekitar dan memberikan pendidikan tentang koperasi kepada anggota maupun pengurus agar menambah pemahaman tentang koperasi.

Solusinya dari kelemahan dan ancaman untuk koperasi yang ada di wilayah Kecamatan Gunungjati agar koperasinya terus berkembang sebagai wujud dalam pembangunan ekonomi kerakayatan adalah meningkatkan hubungan kerjasama dengan instansi-instansi lain, salah satunya yang sangat sulit diatasi dengan para penyediaan pinjaman informan (tengkulak) untuk melakukan kerjasama dengan bertujuan saling menguntungkan satu sama lain. melakukan promosi terusmenerus agar pangsa pasar dapat terjangkau, selalu berinovasi agar koperasi mendapatkan kepercayaan kembali dari masyarakat.

Kehadiran koperasi di Kecamatan Gunungjati salah satunya yang sudah membantu masyarakat dalam pembangunan ekonomi kerakyatan yang sekarang sudah maju dan berkembang yaitu koperasi Simpan Pinjam dan Pembiayaan Syariah dapat kita sebut KSPPS Perambabulan AlQomariyah yang sehat dibandingkan dengan koperasi yang lainnya, karena cukup berkontribusi dalam peningkatan dan pengembangan Usaha kecil mikro dan menengah (UMKM), memberikan solusi terbaik bagi para penguasaha kecil terutama di sektor pembiayaan. KSPPS memberikan keringanan persyaratan administrasi dan kecepatan pelayanan sehingga para pengusaha kecil yang memiliki masalad dalam hal permodalan dapat dengan mudah melakukan peminjaman karena sistem operasionalnya tidak menggunakan bunga melainkan bagi hasil. ${ }^{30}$

Koperasi Simpan Pinjam dan Pembiayaan Syariah memiliki program berupa pendidikan, pelatihan keterampilan wirausaha dan pendampingan bagi anggota yang melakukan peminjaman sebagai upaya memperkuat kualitas UMKM.Selain pendampingan, juga dilakukan pengawasan kepada anggota yang meminjam uang sehingga adanya kejelasan apakah uang tersebut digunakan untuk hal-hal yang sesuai syariah atau yang menentang syariah. Adapun dalam meminimalisir permasalahan kredit macet, KSPPS selalu melakukan analisis kredit dengan program pendampingan sehingga memudahkan KSPPS mengetahui perkembangan dana yang diberikan kepada anggota, selain dengan analisis kredit, pihak KSPPS juga menyediakan dana cadangan kerugian piutang yang bersumber dari zakat, infak, dan sodaqoh. Mengingat begitu pentingnya UMKM dalam memperkuat perekonomian Indonesia khususnya masyarakat Gunungjati, pemerintah seharusnya memberi perhatian lebih pada KSPPS ataupun koperasi lain yang ada di Kecamatan Gunungjati sebagai menompang keberlangsungan pengembangan UMKM.

\section{KESIMPULAN}

Kesimpulan dalam penulisan ini adalah yang pertama, kekuatan koperasi di Kecamatan Gunungjati yaitu, manajemen organisasi yang didukung dengan aplikasi keuangan, sudah mempunyai kantor sendiri tempatnya yang sangat stategis, dengan

${ }^{30}$ Hasil wawancara dengan bapak Agus Wahyudin Koperasi Parambabulan pada tanggal 7 Juni 2018. 
mempunyai inventaris mobil maka mempermudah dalam promosi, mempunyai karyawan khususnya di marketing dan anggota sebagai pemilik dan pengguna.

Kedua, kelemahan koperasi di Kecamatan Gunungjati yaitu, lemahnya kepercayaan masyarakat terutama terkait figur dari pengelola koperasi, tingkat kemampuan dan profesionalisme sumber daya manusia yang belum memadai, keuangan masih lemah dibandingkan dengan perbankan, menerapkan pola syariah yang belum maksimal, belum mempunyai Lembaga Pinjamin Simpanan (LPS).

Ketiga, peluang koperasi di Kecamatan Gunungjati yaitu, terbangunnya kerjasama dengan lembaga keuangan terutama dalam pembiyaan dan pelayanan jasa, mengikuti perkembangan teknologi informasi yang semakin maju, memberikan pelayanan jasa keuangan yang lebih profesional, berkualitas dan barokah, peningkatan manajemen dalam permodalan, mengembangkan koperasi diluar Desa, penambahan marketing.

Keempat, ancaman koperasi di Kecamatan Gunungjati yaitu, penyediaan pinjam informan (tengkulak) yang memberikan pinjaman tanpa tanggungan, mudah, dan cepat, persaingan dengan instansi-instansi lainnya, pangsa pasar tidak terjangkau, adanya cemburuan sosial antara anggota.

Dan kelima, Solusi dari kekuatan dan peluang untuk koperasi yang ada di wilayah Kecamatan Gunungjati agar koperasinya berkembang sebagai wujud dalam pembangunan ekonomi kerakayatan adalah koperasi yang kuat atau sehat dalam sistem manajemen yang diterapkan sesuai dengan peraturan Undang-Undang No. 25 Tahun 1992 dan didukung dengan menggunakan sistem aplikasi keuangan yang mempermudah dalam mengerjakan pekerjaan, sumber daya manusianya kuat maka akan mempengaruhi penambahan modal koperasi dengan melakukan kerjasama dengan perbankan maupun dengan koperasi lainnya. Meningkatkan promosi dengan memberikan pembuktian bahwa keberadaan koperasi sangat membantu membangun perekonomian rakyat menengah, sehingga koperasi mendapatkan kepercayaan kembali dari masyarakat sekitar dan memberikan pendidikan tentang koperasi kepada anggota maupun pengurus agar menambah pemahaman tentang koperasi.

Solusi dari kelemahan dan ancaman untuk koperasi yang ada di wilayah Kecamatan Gunungjati agar koperasinya terus berkembang sebagai wujud dalam pembangunan ekonomi kerakayatan adalah meningkatkan hubungan kerjasama dengan instansi-instansi lain, salah satunya yang sangat sulit diatasi dengan para penyediaan pinjaman informan (tengkulak) untuk melakukan kerjasama dengan bertujuan saling menguntungkan satu sama lain. melakukan promosi terus-menerus agar pangsa pasar dapat terjangkau, selalu berinovasi agar koperasi mendapatkan kepercayaan kembali dari masyarakat.

\section{DAFTAR PUSTAKA}

Amalia, Euis. Keadilan Distrubusi Dalam Ekonomi Islam Penguatan Peran LKM dan UKM di Indonesia. Jakarta: Rajawali Pers, 2009.

Anoraga, Pandji dan Ninik Widiyanti. Dinamika Koperasi. Jakarta: PT. Rineka Cipta, 2007.

Arikunto, Suharsimi. Prosedur Penelitian. Jakarta: PT. Raja Grafindo Persada, 1993.

Bashith, Abdul. Ekonomi Kemasyarakatan. Bandung: UIN-Maliki Press, 2012.

Creswell, John W. Research Design Pendekatan Kualitatif, Kuantitatif, dan Mixed. Yogyakarta: Pustaka Pelajar, 2013.

Darmadi. "Peranan KJKS BMT El-Gunung Jati Terhadap Pemberdayaan Ekonomi Masyarakat (Studi kasus pada nasabah KJKS BMT ElGunung Jati)", Skripsi. Cirebon: Muamalah Ekonomi Perbankan Islam IAIN Syekh Nurjati, 2013. 
Edi Swasono, Sri. Koperasi: Nilai-Tambah Ekonomi, Nilai-Tambah SosialKultural, Sokoguru Perekonomian. Jakarta: Yayasan Hatta, 2005.

Emzir. Metodologi Penelitian Kualitatif: Analisis Data. Jakarta: Rajawali Press, 2012.

Handayani, Udin. "Rekapitulasi Koperasi di Kabupaten Cirebon Tahun 2015", Makalah.Cirebon: Koperasi dan Usaha Mikro Kecil Menengah, 2017.

Heriyono. "Peran Koperasi dalam Pengembangan Perekonomian Rakyat", Jurnal Ekonomi, Vol. 1, No. 1 (Desember, 2012).

Lidwa Pusaka i-Software, Kitab 9 Imam Kutubut Tis'ah, 2009.

Moeleong, Lexy J. Metodologi Penelitian Kualitatif. Bandung: PT. Remaja Rosdakarya, 2013.

Narbuko, Cholid dan Abu Ahmadi, Metodologi Penelitian. Jakarta: Bumi Aksara, 2007.

Nawawi, Ismail. Fikih Muamalah Klasik dan Kontemporer. Bogor: Ghalia Indonesia, 2012.

Noor, Juliansyah. Metodologi Penelitian Skripsi, Tesis, Disertasi dan Karya Ilmiah. Jakarta: Kencana, 2011.

Nugroho, Luthf Novian Dwi. "Peranan Koperasi Simpan Pinjam terhadap Kesejahteraan Anggota (studi kasus di Koperasi Ampera Indonesia)", Skripsi. Cirebon: Program Studi Ekonomi Perbankan Islam IAIN Syekh Nurjati, 2015.

Rozalinda. Fikih Ekonomi Syariah. Jakarta: Rajawali Pers, 2016.

Sugiyono. Metode Penelitian Kualitatif dan $R \& D$. Bandung: C.V. Alfabeta, 2012.

Suhendi, Hendi. Fiqh Muamalah. Jakarta: Rajawali Pers, 2013.

Sumarsono, Sonny. Manajemen Koperasi (Teori dan Praktik). Yogyakarta: Graha Ilmu, 2003.
Sumawinata, Sarbini. Politik Ekonomi Kerakyatan. Jakarta: Gramedia Pustaka Utama, 2004. 